\title{
Social Engineering on Mangrove Preservation Based on Fishermen's Local Wisdom
}

\author{
${ }^{1}$ EDY SUYANTO, ${ }^{2}$ FX.WARDIYONO, ${ }^{3}$ SOTYANIA WARDHIANA, \\ ${ }^{4}$ HENDRI RESTUADHI \\ 1,2,3,4 Prodi Sosiologi, Fakultas Ilmu Sosial dan Ilmu Pemerintahan, Universitas Soedirman, Purwokerto. \\ email: ${ }^{1}$ edysuyanto60@yahoo.co.id; ${ }^{2}$ fxwardiono@gmail.com; ${ }^{3}$ in_noel@yahoo.com; ${ }^{4}$ iki_hendri@yahoo.com
}

\begin{abstract}
Kampung Laut Segara Anakan is a mangrove forest area which has a wealth of biodiversity and ecotourism. For a couple of years, mangrove forest has suffered the destruction caused by the lack of wise (immanent) and not transcendent. It is necessary to conduct social engineering in form of revitalization of mangrove management to cope with the decrease in mangrove ecosystems. The objective of this study is to explore issues among fishermen about environmental management in mangrove forests management to embody innovative village. The method used is a combination of qualitative and quantitative with a purposive sampling technique. The research sites conducted in two villages. The objects of this research are the fishermen communities, NGOs, Community Association of Fishermen, village authorities, and environmental Pioneer activists. The results show that the awareness of fishermen to the existence of mangrove forest is relatively low, Kampung Laut local wisdom has undergone changes due to sedimentation and lifestyle.
\end{abstract}

Keywords: social engineering, local wisdom, mangrove forest

\section{Introduction}

The administration of President Joko Widodo has a vision and mission to prioritize maritime program. Thus, the Coordinating Ministry has programmed a model maritime coastal villages, while the Ministry of Research and Technology \& Higher Education (KemenristekDikti) and the Ministry of Public Works have a model program for the implementation of innovative fishing village of Kampung Laut Segara Anakan. The program is implemented in the late 2017 and it is expected that a thousand (1000) of fishermen innovative villages will be formed in 2019 (Darmawan, 2016: 14).

Kampung Laut is part of Segara Anakan and becomes a barrier to prevent the entry of people from outside the area. Segara Anakan is an island which covers about $12,106.43$ ha and becomes one of the last heritage of coastal forest ecosystems and tropical forests in Java island (Fatma, 2008). Not only it is a home to the thousands of biota,
Segara Anakan is also a place for endangered species which currently threatened with extinction. Biodiversity includes a typical dolphin called wesut (Orcaella sp), which tends to be decreased in number. It is caused by the changes in natural habitats, such as the making of pier, "clearing" activity of mangrove forests, water traffic which is getting crowded, lack of feed resources, environmental pollution, and sedimentation (Sagala at al., 2013: 8).

Flora mangroves in Segara Anakan currently have about 27 mangroves species consists of 13 major species, 8 minor species and six plant association species. LPP Mangrove (Research and Training Institution) BPKSA (Segara Anakan Area Management Institution) noted that the constituent species of mangrove forest in Segara Anakan Region consists of various types with high levels of diversity.

Mangrove forest ecosystems are functioned as sediment traps and erosion

Received: September 12, 2016, Revision: April 04, 2017, Accepted: May 19, 2017

Print ISSN: 0215-8175; Online ISSN: 2303-2499.

Accredited by DIKTI. SK Kemendikbud, No.040/P/2014, valid 18-02-2014 until 18-02-2019, Indexed by DOAJ 
barriers so they can protect another water area. Besides, they have also a function as coastal areas' protection from damage caused by waves and storms. Camilie Brown divides the mangrove forest ecosystem into four domains, namely (a) proliferation of marine life and environment function; (b) protecting and preserving function of the coral reefs, erosion control, absorbent and recycle medium of human waste and other pollutants, preserve biodiversity, a place for migration habitat, spawning and nursery places, the supply of nutrients and nutrient regeneration; (c) economic function include recreation, habitat for indigenous peoples, rice farming, aquaculture and industry and land use; (d) local wisdom. Mangrove area in Segara Anakan has great potential as a wealth of biodiversity, means of academic, research and typical ecotourism.

However, there are various mangrove damages due to the land conversion, which causing a decline in the quality and quantity of mangrove ecosystems. It caused the unoptimal function of mangrove forests both ecologically and socio-economic (Sarno et al., 2008: 10). In 1998, Segara Anakan covered about 6,450 ha, but in 2003 the extent area was only 1,400 ha, according to satellite imagery that captured the breadth of the area on September 2007, it was only 600 ha left (BPKSA, 2008: 4). Overcoming further degradation of mangrove forest, it requires the active participation of fishermen in mangrove conservation by changing the paradigm of transcendent into immanent, from anthopocentrism understanding into biocentrism and ecocentrism understanding.

Kampung Laut Segara Anakan is known for its mangrove forest with an area of 14 519 ha. Data from BPKSA mentioned that Segara Anakan area was getting shrunk. It is noted that in 1903 it was 6,450 ha; in 1939 it is recorded 6,060 ha; in 1971 it is down to $4290 \mathrm{ha}$; in 1992 it was 1,800 ha; in 1999 it is recorded 1,400 ha; and in 2000 it was recorded 500-600 ha. Segara Anakan covers an area of $34,018.62$ hectares consisting of $26,780.65$ ha of land and 7237.97 ha of waters. The development of mangrove forests are as follows: (a) in 1974 the extent of $15,551 \mathrm{ha}$; (b) in 1978 of 10,975 ha; (c) in 1994 of 8,975 ha; and (d) in 2003 the extent of 8359 ha (BPKSA, 2008: 6).

Segara Anakan and Kampung Laut is an estuary ecosystem consisting of several close ecosystems. The decreasing of mangrove forests area had a great impact on the ecology and the society life of Kampung Laut. It caused by human behaviour that transcendent instead of immanent. Environmental impacts arise, including the reduction of fish potential that live in the lagoon, a reduction of the defense wall to hold big storm or tsunami if it occurs at any time, and the increased intensity of erosion and salinity. In Socioeconomic, slowly but surely, the fishermen suffered the decline of income in catching fish and shrimp.

The problem defined is how does cultural tradition of people local wisdom as a social capital in Kampung Laut Segara Anakan mangrove forest management, and who are the actors or influential figures in social engin e ering programs to empower the Kampung Laut communities? The aim of this research is to analyze the fishermen cultural tradition related to mangrove forest conservation in Segara Anakan in order to realize innovative fishing village and analyze the figures or the dominant actors in social engineering to empower communities in order to conservate mangrove forest as typical agrotourism development of Segara Anakan.

\section{Research Methodology}

The method used is a combination of qualitative and quantitative methods. Qualitative research used embedded research with interactive analysis and content analysis, while Quantitative research using descriptive and secondary data analysis and Analysis Hierarchy Process. The research was conducted in two villages, namely Ujung Alang and Ujung Gagak, by taking the primary and secondary data. Technical data retrieval are: (a) a structured and in depth interview; (b) focus group discussion; (c) participation observation.

\section{Local Wisdom of Kampung Laut Segara Anakan's Fishermen}

Segara Anakan is a natural laboratory for researchers both local and abroad in a variety of disciplines. Segara Anakan is very useful lagoon, from social economic to mangrove ecosystem. The mangrove ecosystem in this region includes the life cycle of fish, shrimp, crabs and other faunas, such as birds and various reptiles. This lagoon is a breeding ground for marine animals babies before they go to the high seas of the Indian Ocean (Sudarmadji, 2011:15).

Kampung Laut indigenous people have myths that they were the descendants of 
the Mataram soldier who came to Kampung Laut to secure the water in Segara Anakan. The soldiers were led by four people of wiratamtama (soldiers), named Jaga Playa, Jaga Praya, Jaga Resmi and Jaga Laut. Once the state is safe, the wiratamtama and his men did not return to the center of Mataram Kingdom, and stayed in Cilacap region and surrounding areas. Jaga Praya and Jaga Playa settled in the area which now called Klapalima, while Jaga Resmi and Jaga Laut chose to live in Nusakambangan island. Jaga Resmi settled in what is now called Legok Pari, while jaga Laut resides in Gebang Kuning or now better known by the name of Kembang Kuning. Another name of Kampung Laut is Bejagan or Pejagan. Kampung Laut fishing communities often hear the word of Mbah Jaga Laut (Sagala, 2013: 11).

In Sedekah Laut procession (the ceremony of throwing the offerings to the sea), Jolen-Jolen (some sort of decorated container for the offerings) was brought to the Teluk Penyu accompanied by an art performances. Sea alms myth implemented as a form of gratitude for the peace of the sea in the Segara Anakan. The sea alms ceremony raises pros and cons on the community, where the cleric who thought that this ceremony as shirk, even if it wrapped in a degree of regional culture. It caused by the dumping grain into the sea as a mark to get rid of the unfortunate fates, something which considered dosa and strictly forbidden in Islam (Sarno, Moh. Rodho, 2008: 17).

\section{Environmental Analysis of Social Economic Cultural of Segara Anakan Fishermen}

Segara Anakan economic conditions depend on the catch and the season. The division of the catches is $50 \%$ for ship owners and $50 \%$ for fishermen at sea. The catch division of ship's labor is 5: 1 shared with the ship's captain. Another income obtained from selling fish, including processed salted fish and some of them are also work making salted fish.

Post sedimentation, fishermen's income decreased significantly and make them confused, but it did not last long. Romo Carrolus along with YSBS, trying to alleviate poverty due to sedimentation in Kampung Laut,. With the formulation of the program and financed by foreign aid, he conducted sustainable agricultural methods and provide farm tools. However, Village Community in
Ujung Alang and Ujung Gagak, went back to fishing. This is due to the opportunity in the sea which is bigger than the farm, where they do not need to plant fish but can directly harvest them.

Tenure conflicts and land often occur because of the "annexation" by residents outside Kampung Laut. Another problem is the ownership of motorcycles. Researchers around the village area found that almost $90 \%$ of every house has motorcycle with the machine's production year ranging from 2005-2015. Surprisingly, almost $85 \%$ of those motorcycles have no license plate number and letters (bulging).

\section{Social Engineering at Mangrove Forest Conservation Based on Local Wisdom}

If local wisdom is managed well, it can be a basic for mangrove forest conservation. Mangrove forest conservation model in Segara Anakan was conducted in social engineering of fishermen community empowerment. It is a development strategy by conducting an action to conservate mangrove forest through highly active participation of fishermen and other actors integratedly and sustainably.

This is in line with the previous research which showed that community participation has wide dimension in mangrove forest management. Participation is formed by the driving factors such as needs, expectations, motives and moral support as well as local culture (Suyanto, at al., 2015:9).

Local wisdom has a distinctive significance related to the preservation of mangrove in Segara Anakan. According to Roikhwanphut Mungmachon (2012), local knowledge is fundamental knowledge gained from living in balance with nature. The local wisdom related to the culture and community experiences. Mangrove is a new phenomenon to a public of Segara Anakan. However, as a society accustomed to living with nature, mangrove simply become a part of life of Segara Anakan. Along with the growth of economic needs in society, mangrove is not just a companion for community life, but unfortunately, some irresponsible residents have used it recklessly so it can damage the mangrove itself. Considering that, the participation of mangrove management activity requires an initial phase of socialization to the fishermen. As pointed out by Mintarti, socialization is the process for human beings to learn the ways of life with a variety of 
cultures that exist (Mintarti, at al., 2013 : 9).

\section{Social Engineering of Biota in Mangrove Forest Conservation}

Research conducted by academic showed that mangrove forest is not only a shelter area for biota that live in mangrove ecosystems, but also a place foraging. This occurred because mangroves are the primary producers able to produce large amounts of falling leaves, and branches of mangrove trees served as food for biota in that area. The mangrove areas also known as spawning ground for certain fish to be protected from predatory fish and finding an optimal environment for splits and raise its babies. Mangrove is also become a supplier of shrimp larvae, fish and other organisms such as crabs, lobster etc. (Woodhead, 2000 : 59).

The research conducted by Ocean and Coastal Policy Program Duke University stated that the uptake of 1 (one) hectare of mangrove forest is equal to the absorption of 3-5 hectares of tropical forest. Mangrove forest categorized as wetlands and able to keep 800-1.200 ton of CO2 equivalent per hectare (Martosubroto at al., 1974 :19)

\section{Social Engineering on KridaWanaL- estari as Pioneering Actor of Man- grove Forest Conservation in Segara Anakan}

Head of Marine Fisheries and Resource Management Region of Segara Anakan (DKP2SKSA) stated that after long time there were no efforts and strategies in the Segara Anakan mangrove forests management, but starting in 2016, the rescue of mangrove forest management is carried out by dredging after AMDAL study for the implementation in 2017. Based on available data, the volume of mud dredged was planned to reach about 2.5 million cubic meters ( $\mathrm{m} 3$ ). If dredging activity were not conducted, there would be a loss of mangrove forest because every beginning of a year, there was approximately 1 million $\mathrm{m} 3$ of silt went into the lagoon barrier between the mainland city and Nusakambangan island in Cilacap. The sediment came from two major rivers of Citanduy and Cimeneng that flew to Segara Anakan, The current water depth is up to 9 meters from the surface of the water. The actors behind this activity are the Head of subdistrict of Kampung Laut, Ministry of Public Works, NGOs, mangrove community, academics and DKP2SKSA, while the executor of the activity is the House of Citanduy River
Basin (Darmawan, 2016: 23).

\section{Mangrove Forests' Social Engineering on Laboratory Procurement}

Social engineering in order to rescue Segara Anakan from sedimentation process, must be followed by the restoration or rehabilitation of mangrove forests. It is because Segara Anakan and mangrove forests can not be separated. Didik, the Secretay of subdistrict in Kampung Laut, argued that mangrove rehabilitation efforts in Segara Anakan can not be parted from environmental conditions as a result of sedimentation. The fishermen are mostly unaware of the importance of mangrove forests for the life and breeding of marine life, due to the lack of understanding about the important value of environment.

One of the efforts to improve the quantity and quality of mangrove forests and the welfare of fishermen is by conducting mangrove rehabilitation in mangrove forest area. Therefore, it is necessary to change the fishermen's behaviour in preserving mangrove forest and start to change the paradigm from anthropocentrism to biocentrism understanding even ecocentrism.

Arboretum Mangrove Laboratory in Lempong Pucung, Ujung Alang, initiated by "TH" Wahyono. Along with a group Krida Wana Lestari he said that initial mangrove laboratory is a collaboration of local governments, private sector and community groups.

DKP2SKSA mentioned that in 2016 there were approximately 35 species of mangrove plants in the arboretum area. The local area is also used for seeding mangrove lands managed by community groups. They make efforts to continue greening mangrove every day and on July 2016 they have successfully expanded the green area of mangrove up to 160 ha. It showed there has been a rehabilitation and reforestation of mangrove significantly.

Group care of environment members has contributed in the rehabilitation of mangrove forest management in Segara Anakan in form of developing mangrove seedlings. Mangrove seedling is not only useful in greening $\mathrm{K}$ ampung Laut region and Segara Anakan, but also for another surrounding area as well. "We often get orders of mangrove seedlings from other areas. In 2015, there was an order of 250 thousand mangrove seedlings, and in early 2016 up 
until now it has reached 200 thousand of mangrove seedlings distributed and planted," said one of the members.

\section{Social Engineering in Segara Anakan Dredging Activities}

Mangrove forests have been declined from year to year. This is negatively affecting the lives of fishermen and also the growth of fish and other marine life. Therefore, the effort should be taken to overcome the worsening of mangrove forests, which caused sedimentation in river of Segara Anakan region.

Residents hope that the central government would undertake rehabilitation and reforestation in Segara Anakan by dredging sedimentation immediately. In 2016, Segara Anakan was experiencing a siltification up to 7 meters. Sedimentation often lead to conflicts of land tenure issues. Citing the tagline of "Lush the Mangrove, Prosperous the Society", mangrove is not only the last bastion of the coastal area, but also houses for a variety of fish, shrimp, crabs and other wildlife (Rasyid Ridho, 2008 : 14).

Actors who play a role in dredging program proposal efforts are Mangrove community, the Government, NGOs concerned with environment and society, NGO of YSBS with Romo Carolus who empowering people in the agriculture field and poverty alleviation. He worked with the aid from foreign party or overseas. Sagala et al. (2013) stated that the indicators of network interaction among the parties are variables and parameters indicators.

\section{Social Engineering on Pioneers Ac- tors of Mangrove Forest Environmen- tally Awareness Movement}

The empowerment process can not be done without the involvement of the dominant and influenced actors. According to Julian Rappaport (1987), empowerment or social engineering is the process where people, organizations and communities seek to control and regulate the environment. The problem is, to arrive at such process, it takes actors who first could be a pioneer in that movement. This study indicate that one of the environmental pioneer actor in Segara Anakan is "TH." This man comes from Lempong Pucung, Ujung Alang. He, who known as "TH". start the "green" action since 2001 and currently being the head of Lempong Pucung in Ujung Alang.
"TH" stated that when he was active in the management of mangrove forests, the condition of mangrove in Ujung Alang was badly damaged. Previous investors in Kampung Laut Segara Anakan cut down mangroves forest to change it into aquaculture fish. It lasted for few years. The economic crisis of 1998 cause the investors left Kampung Laut Segara Anakan with severely damaged mangrove forests condition. Starting from that condition, "TH" took his family back to green the mangrove. When he initially started, his only purpose is to green the mangrove. It was due to the fact that the area that was once green become hot because of the opening of mangrove forests. At that time, many people scoffed at him. However, it made him (Wahyono) more driven in his work with his family. Although his action considered strange, he finally succeed.

"TH" established Krida Wana Lestari movement groups. It received positive response from Ujung Alang villagers. Communities saw the mangrove planting activity is good for people's lives and mangrove

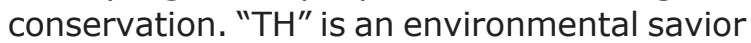
actor who worked for 8 years greening the region which covers dozens of hectares. Pertamina Refinery Unit (RU) IV Cilacap began to look at his action and made his group as Pertamina's partners of CSR. "TH" said that he was so surprise to find a party who are interested in providing assistance. The group changed its name to Patra Krida Lestari. The guidance from the group has helped expanding the greening action which now has reached 30 ha.

According to Max Weber (Morris \& Herring, 1984:63), "TH" have charismatic authority through a series of experiences in mangrove rescue function. Activities performed by "TH" were a logical consequence of the situation in Segara Anakan. "TH" attempted to change the values and break the traditional norms and rational existing related to the presence of mangroves in his region. TH's struggle was the charismatic movement that aimed for change and welfare of Segara Anakan society in general.

"TH" revealed that he cultivated crabs and fish in an environment that has been overgrown with mangrove. The results were very good. For the 0.5 hectares of land, for example, it was able to produce three hundred pounds of fish. If it sold, it can make money around Rp 4,800,000.00. Whereas, the current capital is about Rp 600.000,00. 
Likewise, for crab, the results were able to

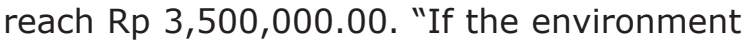
is not reforested with mangrove, it was impossible to get result like this," said "TH". The actor was also awarded an Environmental Pioneer Actor in Central Java in 2010 and the Coastal Rescue Actor by KEMENKP in 2011.

In 2016, "TH" was not just invite people to do the farming in mangrove areas, but also he tried to captivate all types of mangrove plants. Now, he has been able to make 20 types of mangrove seedlings. In September 2016, Pertamina RU IV Cilacap building Mangrove Conservation and Indonesian Germplasm Study Center in this village, Ujung Alang and inaugurated by Minister of Environment at the time.

According to " $\mathrm{TH}$ ", it was not only Patra Krida Lestari who played a role in the conservation, but there were experts from Unsoed (University of Soedirman) and IPB (Bogor Farming Institute) took part in it. Sustainable mangrove forest brings sustenance in forming typical agro tourism.

Social Engineering of Community Empowerment in the 71st Indonesia's Independence Day to Deliver Agro Tourism Forest

Head of Kampung Laut subdistrict (2016) intentionally held a ceremony of 71st Indonesian Independence Day in 2016 and carnaval of Segara Anakan waters. It is aimed to commemorate the existing of mangrove forest. The driving actor in community empowerment activity is Mujiono, Vice Chairman of the Regional Parliament of Cilacap, who told to Satellites Post that "the implementation of the Independence Day on the sea is not only as a commemoration and foster nationalism, but also a momentum to develop eco-tourism in the mangrove forest in Segara Anakan. In 2017, it is expected to hold Independence Day Commemoration at regency level in Segara Anakan, and it can become an annual agenda of Kampung Laut tourism destination.

\section{Knowledge, Attitudes and Participa- tion in Mangrove Forest Management}

The results of this research showed that in general, about $56 \%$ of fishermen do not understand the management of mangrove forests. $20 \%$ of them know but do not understand, and only a small proportion of $16 \%$ fishermen understand about the management of mangrove forest. Regarding the perception or assessment of fishermen about mangrove forest management in Segara Anakan, it is found that the fishermen who have less well perception on mangrove forest management was 34\%, the negative perception was $34 \%$, and only a small portion of $24 \%$ perceived it good. $54 \%$ of the fishermen's behavior on the mangrove forest management are generally do not support the mangrove forest management, while $14 \%$ of them supported it, while $36 \%$ considered it less well. The behavior of fishermen will affect their participation in the management of mangrove forests which resulted as follow: did not participate of $46 \%$, participate occassionally of $32 \%$, and actively participate in the management of mangrove forests of $22 \%$. Generally, the fishermen's behaviour is concluded transcendent, not immanent, and most of them subscribe the anthropocentrism theory, not ecocentrism.

\section{Conclusions}

Kampung Laut society generally has a poor understanding of the mangrove forest cultivation and function. Mangrove forest area decrease year by year because of fishermen's behaviour. Mangrove forest conservation was conducted by having social engineering based on local wisdom. Land ownership conflict often arises as the result of lack of understanding on the law. On the other hand, motorcycle ownership in general is not equipped with an official vehicles letter, such as Vehicle Ownership Book and Vehicle Registration Number. It is necessary to address the awareness of the law to people in Kampung Laut.

Actors of conservation in Segara Anakan includes (a) the dominant actors in the dredging activity: Head of subdistrict, Ministry of Public Work, DKP2SKSA and the university campuses. (b) the dominant actors in the procurement activities of laboratory propulsion in Kampung Laut (arboretum) in Segara Anakan as the rehabilitation of mangrove forests are: Head of subdistrict, academicians, and DKP2SKSA official of Cilacap. (c) the actors who play a role in the dredging program of Segara Anakan are: Ministry of Public Work, the Provincial Government, and the public. There was also YSBS with Romo Carolus who played a role in empowering the community in agriculture field to alleviate poverty, (d) the dominant pioneer actor in mangrove forest is " $\mathrm{TH}^{\text {" with }}$ KridaWanaLestari who has deep concerned 
over mangrove forests, (e) the dominant actor of community empowerment efforts to increase tourism in the mangrove forests is the Head of subdistrict.

The solution to strengthening (revitalizing) the capacity of community's social capital (local wisdom) and make people more concerned about the preservation of mangrove forests is social engineering. It is done by counseling using egalitarian approach, such as through community based management approach. It needs an integrated engagement among stakeholders in the mangrove conservation management, including the involvement of students from elementary, junior and senior high school in Kampung Laut area.

\section{References}

Badan Pengelola Kawasan Segara Anakan (BPKSA).(2008). Kajian Akademik Pembentukan Kantor Pengelolaa Sumberdaya Kawasan Segara Anakan. BPKSA, Cilacap.

Darmawan. (2016). Mari Berwisata Mangrove ke Segara Anakan, Pustekom Segara Anakan, BPKSA, Cilacap.

Martosubroto, P dan Sudrajat. (1974). A Study on some ecological aspect and fisher of Segara Anakan In Indonesia. Publ.Of Fish Rest. Inst. LPPL 1/73, pp.73-84.

Mintarti, Dasuki N.P, dan Novianti, W. (2013). "Fungsi Kontrol Sosial Islam dalam Pencegahan Pergaulan Bebas Remaja". Jurnal MIMBAR, LPPM Unisba, Vol. XXIX, No. 2 (Desember), pp 9-18.

Morris, A\& Herring (1984). Theory and Research in Social Movements:A Critical Review. Journal of Political Behavior.
Westview Press.USA.

Mungmachon, R. (2012). Knowledge and Local Wisdom: Community Treasure. International Journal of Humanities and Social Science, Thailand, Vol. 2 No. 13 (July),pp. 67-76..

Rappaport, Julian. (1987). Terms of Empowerment/ Exemplars of Prevention: Toward a Theory for Community Psychology. American Journal of Community Psychology, Vol. 15, No. 2, pp. 132-141.

Ridho, R. (2008). Potensi Sumberdaya Ikan dan Pengembangan Wilayah Pesisir Tanjung Jabung Barat Jambi, Jurnal Pengelolaan Lingkungan dan Sumberdaya Alam, Universitas Jambi Vol. 7, No.3 (September), pp.14-25.

Sarno, M \&Ridho, R. (2008). Mangrove di Segara Anakan: Permasalahan dan Solusinya, Jurnal Pengelolaan Lingkungan dan Sumber Daya Alam, Unsri, Vol.7, No. 3 (September), pp. 17-26.

Sagala, S, Situngkir, F, Wimbarda, R. (2013). Interaksi Aktor Rekonstruksi Rumah Pascabencana Gempa Bumi, Jurnal MIMBAR, LPPM Unisba, Vol. 29, No. 2 (Desember), pp. 8-19.

Suyanto, E, Endriatmo, Sumardjo, \& Hartrisari. (2015). Model Kebijakan Pengelolaan Sampah Berbasis Partisipasi Green Community Mendukung Kota Hijau, Jurnal MIMBAR, LPPM Unisba, Vol. 31, No.1 (Juni), pp. 143-152.

Sudarmadji. (2011). Rehabilitasi Mangrove dengan Pemberdayaan Masyarakat Pesisir, Jurnal Ilmu Dasar, UGM, Vol. 2, No.2 (Juli), pp. 11-20.

Woodhead, T. (2000). Strategic Plan: Conservation of Biodiversity Segara Anakan and Nusakambangan Cilacap. 